\title{
Enantioselective Total Synthesis of Spirofungins A and B
}

\author{
Michael T. Crimmins* and Elizabeth A. O'Bryan \\ Kenan and Caudill Laboratories of Chemistry, University of North Carolina at Chapel Hill, Chapel \\ Hill, North Carolina 27599
}

\author{
Abstract

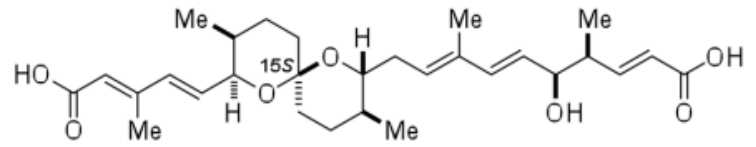 \\ (-)-spirofungin $A(\mathbf{1})(15 S)$ \\ $(+)$-spir ofungin $B(2)(15 R)$
}

\begin{abstract}
The enantioselective total synthesis of spirofungins A (1) and B (2) is reported in 14 steps over the longest linear sequence. Key steps include the use of thiazolidinethione mediated aldol reactions to assemble the major fragments and installation of the $\mathrm{C} 1-\mathrm{C} 6$ side chain using a cross metathesis reaction.
\end{abstract}

Spirofungins A (1) and B (2) were isolated in 1998 as secondary metabolites of Streptomyces violaceusniger Tü 4113 as a 4:1 mixture. ${ }^{1}$ These spiroketal-containing natural products differ only in the configuration about the $\mathrm{C}-15$ spirocenter. ${ }^{2}$ The spirofungins, along with the structurally related reveromycins, ${ }^{3}$ possess high antifungal activity against yeasts, including the human pathogen Candida albicans. Further biological studies by the Kozmin group revealed that spirofungin A suppresses the growth of several human cancer cell lines and selectively inhibits isoleucyl-tRNA synthetase in vitro. ${ }^{4}$ The interesting structure and biological profile of the spirofungins have resulted in two total syntheses ${ }^{4,5}$ as well as several approaches to the spiroketal core. ${ }^{6}$ Additionally, the Shimizu group has begun investigating derivatives of both spirofungin $\mathrm{A}$ and the reveromycins. ${ }^{7}$

Herein, we describe a highly convergent route to (-)-spirofungin A (1) and (+)-spirofungin B (2) in which a cross metathesis reaction would be employed to install the C1-C6 side chain 3 in an efficient manner (Scheme 1). The cross metathesis partner, diene $\mathbf{4}$ or $\mathbf{5}$, was envisioned to arise from the spiroketalization of ketone $\mathbf{6}$, available via a Horner-Wadsworth-Emmons olefination, conjugate reduction sequence. The $\beta$-ketophosphonate $\mathbf{7}$, aldehyde $\mathbf{8}$, and ester $\mathbf{3}$ would be prepared using chiral auxiliary mediated aldol reactions developed in our laboratories. 8,9

Initial efforts were focused on the synthesis of aldehyde 8 . Due to the required anti substitution, this fragment could not be accessed directly from a thiazolidinethione mediated propionate aldol reaction (Scheme 2). Instead, aldehyde $\mathbf{8}$ was prepared via a diastereoselective acetate aldol reaction followed by a Frater-Seebach alkylation. ${ }^{10}$ The acetate aldol reaction between $\mathrm{N}$-acetylthiazolidinethione $9^{9}$ and 3-butenal ${ }^{11}$ gave rise to aldol adduct $\mathbf{1 0}$ in $81 \%$ yield and $>20: 1$ diastereomeric ratio. Direct displacement of the chiral auxiliary ${ }^{8}$ with iso-butyl alcohol

crimmins@email.unc.edu.

Supporting Information Available: Experimental details and spectral data for new compounds. This material is available free of charge via the Internet at http://pubs.acs.org. 
provided ester 11 in $98 \%$ yield. The Frater-Seebach alkylation with methyl iodide proceeded in high diastereoselectivity, however optimization was necessary to improve the rate of conversion. After screening a variety of conditions it was determined that adding DMPU resulted in the highest and most consistent yields. ${ }^{12}$ The alkylated ester $\mathbf{1 2}$ was obtained in $63 \%$ yield and a 10:1 diastereomeric ratio with the optimized conditions. Protection of $\mathbf{1 2}$ as the triethylsilyl ether and reduction of the ester generated aldehyde 8 in five steps and $44 \%$ overall yield.

The synthesis of $\beta$-ketophosphonate $\mathbf{7}$ commenced with an Evans syn propionate aldol addition ${ }^{11}$ between $N$-propionylthiazolidinethione 13 and known aldehyde $\mathbf{1 4}^{13}$ to deliver secondary alcohol $\mathbf{1 5}$ in $88 \%$ yield and $>20: 1$ diastereomeric ratio (Scheme 3 ). The resultant alcohol was protected as the triethylsilyl ether and reductive removal of the thiazolidinethione auxiliary gave rise to aldehyde $\mathbf{1 6}$ in $81 \%$ yield over the two steps.

A Wittig reaction with stabilized ylide $\mathbf{1 7}$ was employed to homologate the aldehyde to the $\alpha, \beta$-unsaturated ester. Upon 1,4-reduction with di-iso-butylaluminum hydride mediated by $\mathrm{MeCu},{ }^{14}$ ester 18 was obtained in $83 \%$ yield. Treatment of ester 18 with lithiated dimethyl methylphosphonate ${ }^{15}$ furnished $\beta$-ketophosphonate 7 in $87 \%$ yield and $48 \%$ overall yield for the six steps.

With both $\beta$-ketophosphonate $\mathbf{7}$ and aldehyde $\mathbf{8}$ in hand, formation of the spiroketal precursor via a modified Horner-Wadsworth-Emmons olefination ${ }^{16}$ was next explored. Treatment of 7 with barium hydroxide followed by addition of aldehyde $\mathbf{8}$ formed the desired C13-14 bond. Conjugate reduction ${ }^{14}$ of the resultant enone generated ketone 6 in $94 \%$ yield. Exposure of the ketone to PPTS in methanol resulted in facile cleavage of the silyl protecting groups and spontaneous spiroketalization to provide a 2:1 mixture of spiroketals 19 (15S-isomer) and 20 (15R-isomer). NOESY and COSY NMR analysis determined that the major product corresponded to the spiroketal core of spirofungin A. The spiroketals were readily separated by flash column chromatography to give $\mathbf{1 9}$ and $\mathbf{2 0}$ in 56\% and 26\% yields respectively, each of which was carried on separately for the remaining steps in the synthesis.

Introduction of the desired oxidation state of $\mathrm{C} 24$ was achieved via a manganese dioxide oxidation employing sodium cyanide and methano ${ }^{17}$ to deliver methyl esters 21 and $\mathbf{2 2}$ each in $78 \%$ yield. To arrive at the desired cross metathesis partner, installation of the C6-C8 diene was accomplished via a sequential cross metathesis/Wittig reaction. ${ }^{18}$ Treatment of $\mathbf{2 1}$ or $\mathbf{2 2}$ with methacrolein and Grubbs second generation catalyst gave rise to enals $\mathbf{2 3}$ and $\mathbf{2 4}$ in $\mathbf{7 4 \%}$ yield. A methylene Wittig ${ }^{19}$ olefination introduced the terminal olefin, providing dienes $\mathbf{4}$ and 5 in $86 \%$ and $75 \%$ yield respectively.

Having developed an efficient route to the spiroketal core, focus was shifted to synthesis and appendage of the $\mathrm{C} 1-\mathrm{C} 6$ side chain. Allylic alcohol $\mathbf{3}$ could be generated in a sequence analogous to that used to prepare $\beta$-ketophosphonate 7 (Scheme 4). Beginning with an Evans syn propionate aldol reaction between $N$-propionylthiazolidinethione $\mathbf{1 3}$ and acrolein gave aldol adduct 25 in $96 \%$ yield and excellent diastereoselectivity. The alcohol was then protected as the triethylsilyl ether and the auxiliary reductively cleaved to deliver aldehyde $\mathbf{2 6}$ in $92 \%$ yield over the two steps. A Wittig reaction with ylide $\mathbf{1 7}$ and removal of the silyl protecting group furnished allylic alcohol $\mathbf{3}$ in excellent yield over the five steps.

The major bond forming event that remained was introduction of the $\mathrm{C} 6-\mathrm{C} 7$ bond via a cross metathesis reaction of either diene with allylic alcohol 3. Based on the previous success of a cross metathesis between a similarly substituted diene and allylic alcohol from our group, ${ }^{20}$ we anticipated the proposed cross metathesis between diene $\mathbf{4}$ or $\mathbf{5}$ and allylic alcohol $\mathbf{3}$ to be selective for the desired $E$ alkene. ${ }^{21}$ While the reaction was highly selective, initial attempts were plagued by low yields and conversion. Several reaction conditions and model substrates 
were examined in order to optimize the key cross metathesis reaction. Ultimately, it was found that to obtain the highest yields, it was necessary to add the ruthenium catalyst as a solution over several hours. Under the optimized conditions, the cross metathesis products $\mathbf{2 7}$ and $\mathbf{2 8}$ were obtained in $83 \%$ and $71 \%$ yield respectively based on recovered diene. Finally, employing conditions used by Shimizu, ${ }^{5}$ hydrolysis of the diester with lithium hydroxide provided (-)spirofungin A (1) in 87\% yield and (+)-spirofungin B (2) in 88\% yield.

In summary, a highly convergent total synthesis of spirofungins A and B has been completed in 14 steps as the longest linear sequence from known aldehyde 14. The key fragments were assembled using the thiazolidinethione mediated propionate and acetate aldol reactions developed in our laboratories. A cross metathesis reaction provided an efficient strategy for appending the right-hand side chain to the spiroketal core.

\section{Supplementary Material}

Refer to Web version on PubMed Central for supplementary material.

\section{Acknowledgments}

Financial support from the National Institute of General Medical Sciences (GM60567) is gratefully acknowledged.

\section{References}

1. Holtzel A, Kempter C, Metzger JW, Jung G, Groth I, Fritz T, Fiedler HP. J Antibiot 1998;51:699-707. [PubMed: 9766461]

2. Zannatta SD, White JM, Rizzacasa MA. Org Lett 2004;6:1041-1044. [PubMed: 15012095]

3. (a) Takahashi H, Osada H, Koshino H, Kudo T, Amano S, Shimizu S, Yoshihama M, Isono K. J Antibiot 1992;45:1409-1413. [PubMed: 1429225] (b) Takahashi H, Osada H, Koshino H, Sasaki M, Onose R, Nakahoshi M, Yoshihama M, Isono K. J Antibiot 1992;45:1414-1419. [PubMed: 1429226] (c) Koshino H, Takahashi H, Osada H, Isono K. J Antibiot 1992;45:1420-1427. [PubMed: 1429227]

4. Marjanovic J, Kozmin SA. Angew Chem Int Ed 2007;46:8854-8857.

5. Shimizu T, Satoh T, Murakoshi K, Sodeoka M. Org Lett 2005;7:5573-5576. [PubMed: 16320994]

6. (a) Shimizu Y, Kiyota H, Oritani T. Tetrahedron Lett 2000;41:3141-3144. (b) Shimizu T, Kusaka J, Ishiyama H, Nakata T. Tetrahedron Lett 2003;44:4965-4968. (c) Dias LC, de Oliveira LG. Org Lett 2004;6:2587-2590. [PubMed: 15255697] (d) La Cruz TE, Rychnovsky SD. Org Lett 2005;7:18731875. [PubMed: 15844928]

7. Shimizu T, Usui T, Fujikura M, Kawatani M, Satoh T, Machida K, Kanoh N, Woo JT, Osada H, Sodeoka M. Bioorg Med Chem Lett 2008;18:3756-3760. [PubMed: 18519164]

8. Crimmins MT, King BW, Tabet EA, Chaudhary KJ. J Org Chem 2001;66:894-902. [PubMed: 11430110]

9. Crimmins MT, Shamszad M. Org Lett 2007;9:149-152. [PubMed: 17192107]

10. (a) Seebach D, Wasmuth D. Helv Chim Acta 1980;63:197-200. (b) Frater G, Müller U, Günther W. Tetrahedron 1984;40:1269-1277.

11. Crimmins MT, Kirincich SJ, Wells AJ, Choy AL. Synth Commun 1998;28:3675-3679.

12. Hareau GP, Koiwa M, Hikichi S, Sato F. J Am Chem Soc 1999;121:3640-3650.

13. (a) Zhang H, Lerro KA, Takekuma S, Baek DJ, Moquin-Pattey C, Boehm MF, Nakanishi K. J Am Chem Soc 1994;116:6823-6831. (b) Suzuki T, Nakada M. Tetrahedron Lett 2002;43:3263-3267.

(c) Clarke PA, Davie RL, Peace S. Tetrahedron 2005;61:2335-2351.

14. Tsuda T, Hayashi T, Satomi H, Kawamoto T, Saegusa T. J Org Chem 1986;51:537-540.

15. Delamarche I, Mosset P. J Org Chem 1994;59:5453-5457.

16. Alvarezibarra C, Arias S, Banon G, Fernandez MJ, Rodriguez M, Sinisterra VJ. J Chem Soc, Chem Commun 1987:1509-1511.

Org Lett. Author manuscript; available in PMC 2011 October 1. 
17. (a) Corey EJ, Gilman NW, Ganem BE. J Am Chem Soc 1968;90:5616-5617. (b) Nyangulu JM, Galka MM, Jadhav A, Gai Y, Graham CM, Nelson KM, Cutler AJ, Taylor DC, Banowetz GM, Abrams SR. J Am Chem Soc 2005;127:1662-1664. [PubMed: 15701000]

18. Paul T, Andrade R. Tetrahedron Lett 2007;48:5367-5370.

19. Wittig G, Haag W. Chem Ber 1955;88:1654-1666.

20. (a) Crimmins MT, Christie HS, Chaudhary K, Long A. J Am Chem Soc 2005;127:13810-13812. [PubMed: 16201800] (b) Crimmins MT, Christie HS, Long A, Chaudhary K. Org Lett 2009;11:831834. [PubMed: 19199767]

21. Chatterjee AK, Choi T, Sanders DP, Grubbs RH. J Am Chem Soc 2003;125:11360-11370. [PubMed: 16220959]

Org Lett. Author manuscript; available in PMC 2011 October 1. 


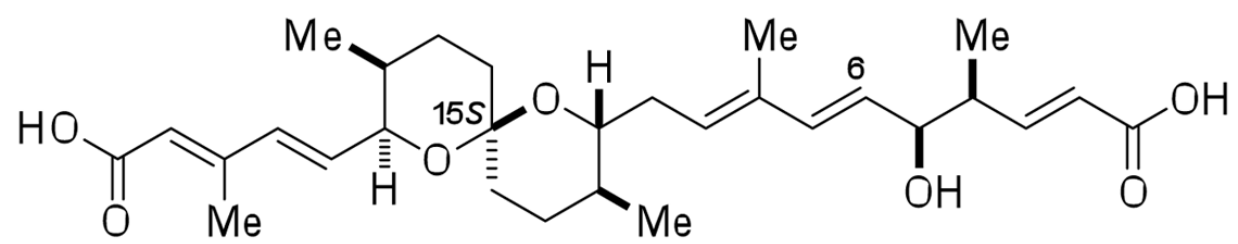

(-)-1 (15S) , (+)-2 (15R)<smiles>[Y16]C(C=CC(=O)OCC)C(O)C=C</smiles>

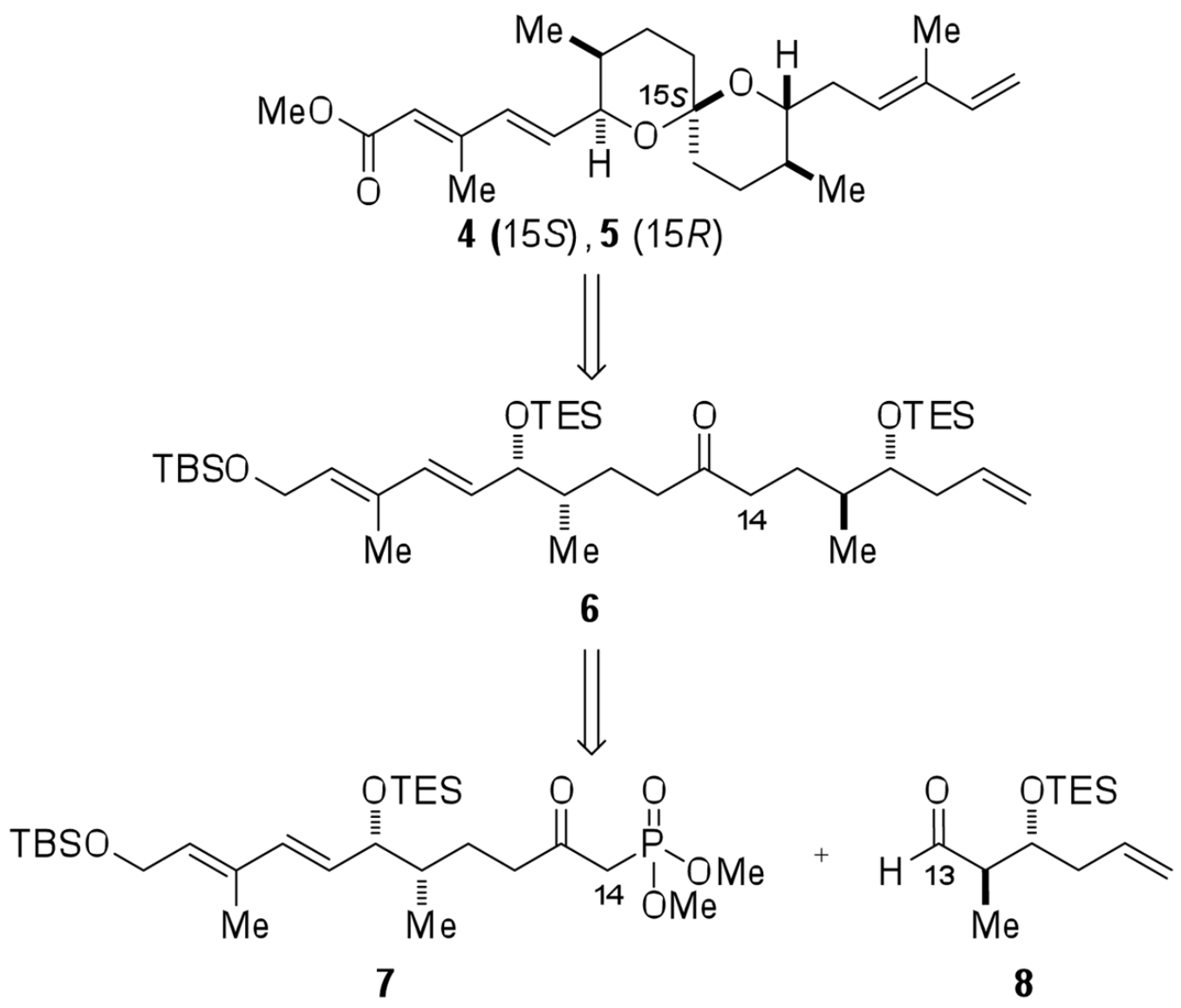

Scheme 1.

Retrosynthetic analysis of the spirofungins. 
<smiles>CC(=O)N1C(=S)SC[C@H]1S(C)(=O)=O</smiles>

9

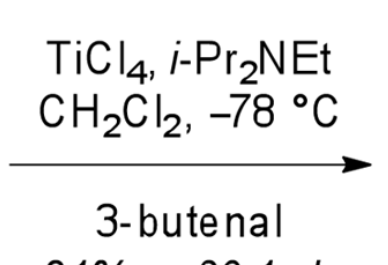

$81 \%,>20: 1 d r$

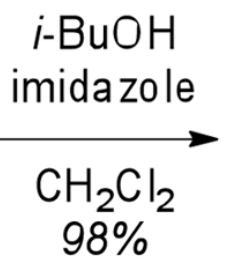

i-BuOH imidazole $98 \%$

Scheme 2

Synthesis of aldehyde $\mathbf{8}$.<smiles>C=CC[C@@H](O)CC(=O)N1C(=S)SC[C@H]1[S@@](=O)[O-]</smiles>

10<smiles>C=CC[C@@H](O)C([14CH3])C(=O)OCC(C)C</smiles>

12<smiles>C=CC[C@H](O)CC(=O)OCC(C)C</smiles>

11

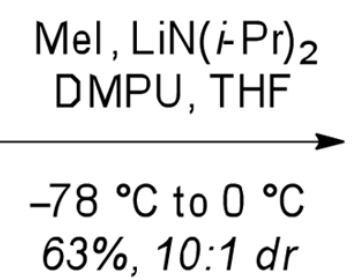
$63 \%, 10: 1 d r$

\section{TESOTf} 2,6-lutidine

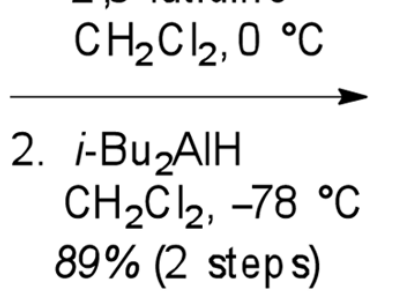<smiles></smiles>

8 

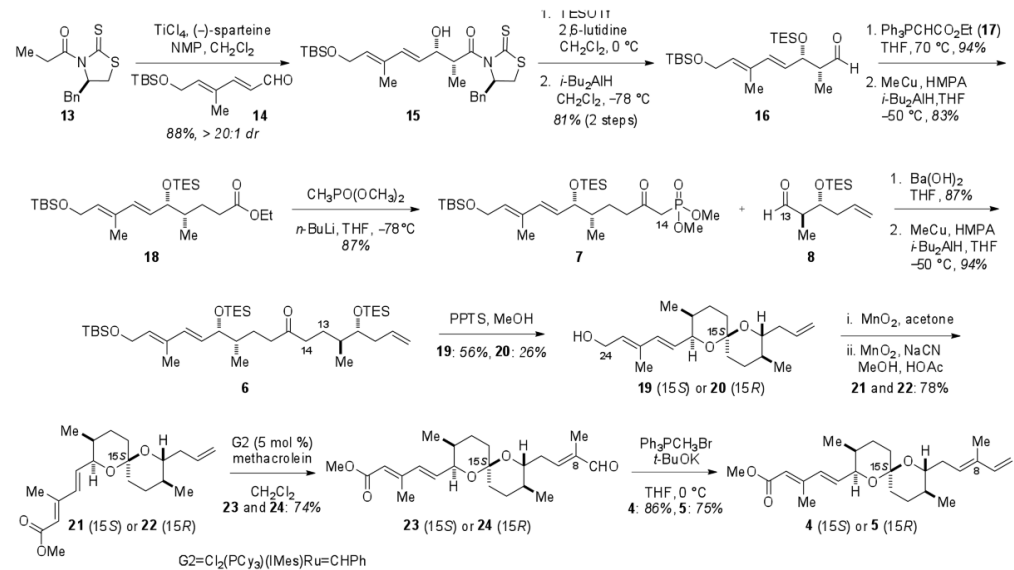

Scheme 3.

Synthesis of spiroketals $\mathbf{4}$ and $\mathbf{5}$.

Org Lett. Author manuscript; available in PMC 2011 October 1. 
<smiles>CCC(=O)N1C(=S)SCC1Br</smiles>

13

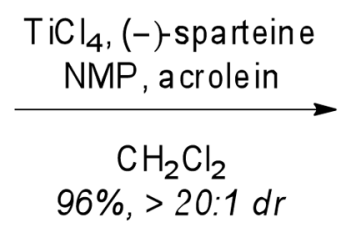

$96 \%,>20: 1 d r$<smiles>C=C[C@H](O)[C@@H](N)C(=O)N1C(=S)SCC1Br</smiles>

25

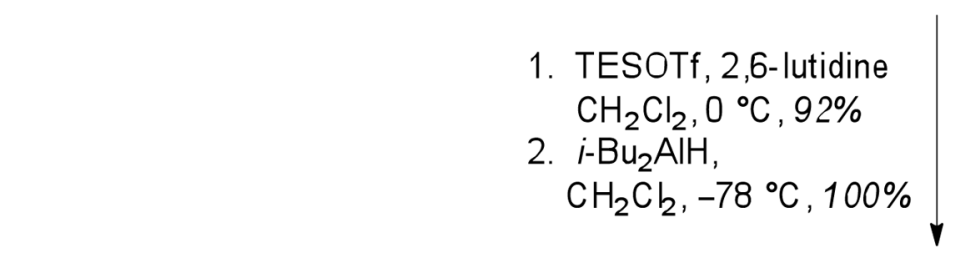<smiles>C=C[C@H](O)[C@@H](C)/C=C/C(=O)OCC</smiles>

3
1. $\mathrm{Ph}_{3} \mathrm{PCHCO}_{2} \mathrm{Et}(17)$ $\mathrm{THF}, 70^{\circ} \mathrm{C}, 91 \%$

2. $n-\mathrm{Bu}_{4} \mathrm{NF}$ THF, 95\%

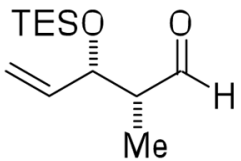

26

Scheme 4.

Synthesis of allylic alcohol 3. 

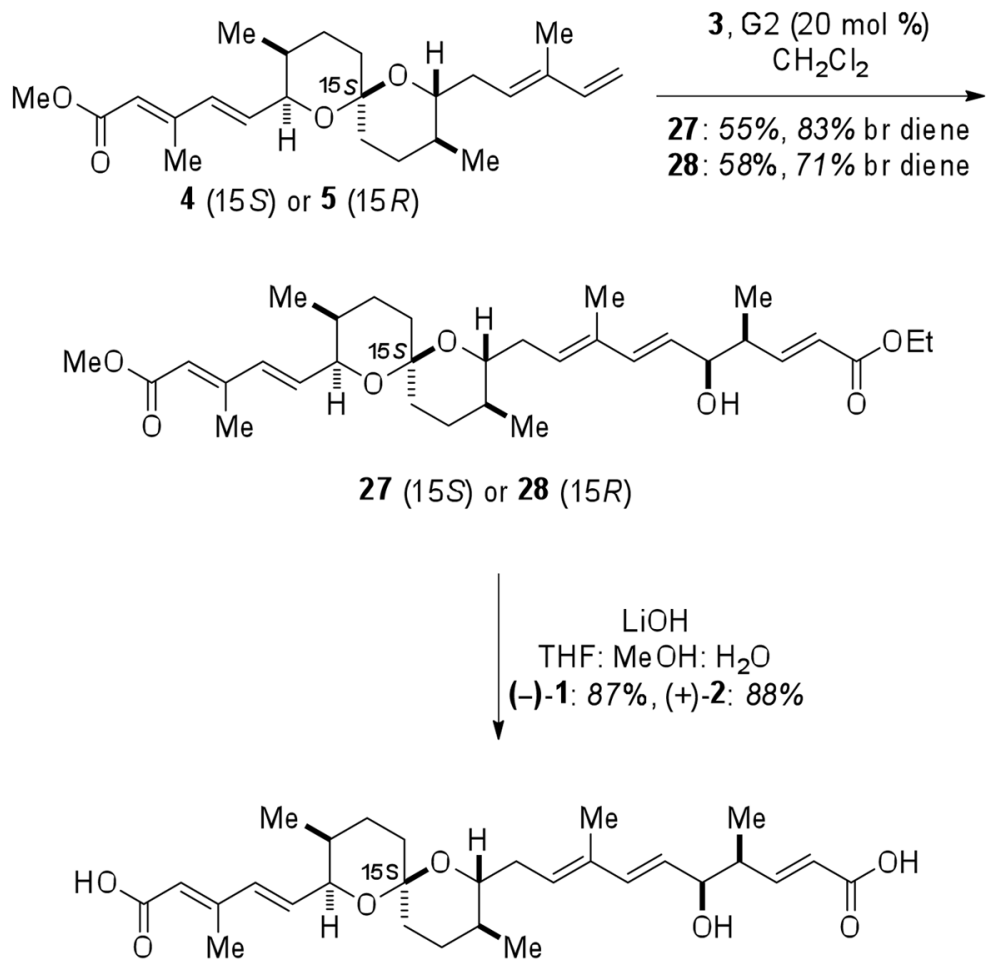

(-)-1 spirofungin $A$

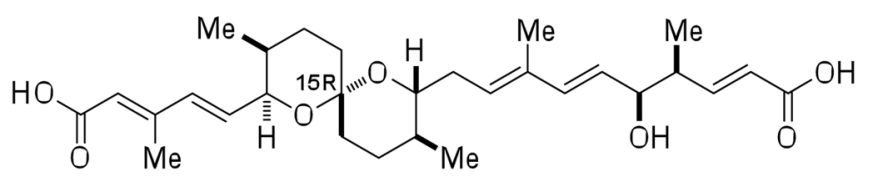

$(+)-2$ spirof ungin $B$

Scheme 5.

Total synthesis of spirofungins A and B. 